\title{
Functional and Morphostructural Evaluation of the Kidneys of Wistar Rats after the Use of a Protein-Based Food Supplement
}

\author{
Andressa Alves de Andrade Silva ${ }^{1}$, Antônio Gonçalves Rodrigues Junior ${ }^{1}$, Avelar Alves da Silva ${ }^{2^{*}}$ and Ana Carolina Alves de Andrade Silva ${ }^{1}$ \\ ${ }^{1}$ FACID DE VRY (Faculdade Integral Diferencial), United States \\ ${ }^{2}$ Department of Nephrology, Federal University of Piaui, University Campus Petronio Portela, United States
}

"Corresponding author: Avelar Alves da Silva, Department of Nephrology, Federal University of Piaui, University Campus Petronio Portela, Teresina, United States, Tel: +558699819904; E-mail: andressa_alves_andrade@hotmail.com

Received date: November 06, 2016; Accepted date: November 22, 2016; Published date: November 29, 2016

Copyright: ( 2016 de Silva AA, et al. This is an open-access article distributed under the terms of the Creative Commons Attribution License; which permits unrestricted use; distribution; and reproduction in any medium; provided the original author and source are credited.

\begin{abstract}
Introduction: Athletes are increasingly using whey protein-based dietary supplements that, used improperly, may create health risks.

Objective: To evaluate changes in glomerular filtration, renal tubular function, and histopathological alterations associated with the use of protein-rich food supplements on the kidneys of Wistar rats.

Method: Twelve Wistar rats were divided into control (Group I) and intervention (Group II) groups. Group II received the supplement for 14 fourteen days. Urine samples were collected from the animals for urinalysis and blood samples were collected for the determination of urea, creatinine, sodium, potassium, and chloride levels. At the end of the experiment, the animals were euthanized and the kidneys were collected for a histopathological study.

Results: After the supplementation, reduced urea levels $(p=0.00930)$ and increased urinary density $(p=0.4645)$ were observed in Group II. The vast majority of Group II animals $(67 \%)$ had significant proteinuria $(p=0.040)$, and epithelial cells and waxy casts occurred in $50 \%$ and $67 \%$, respectively. Histological analysis of the kidneys showed the presence of areas of peritubular blood vessel dilation and congested glomeruli.

Conclusion: Use of the protein supplement changed glomerular filtration and tubular function as evidenced by significantly increased proteinuria as well as peritubular, glomerular, and vascular congestion on histopathological analysis.
\end{abstract}

Keywords: Acute kidney injury; Renal protein overload; Whey protein-based dietary supplements

\section{Introduction}

The use of whey protein-based food supplements has become very popular among athletes in the relentless search for body beauty that permeates modern society. Athletes are increasingly using nutritional supplements, the improper use of which may result in health risks [1]. Whey protein is one of more popular food supplements among athletes. The use of supplements based on commercial proteins and amino acids by athletes and sportsmen is mainly aimed toward replacing dietary proteins and increasing the biological value of food proteins and their anti-catabolic and anabolic effects [2].

Despite numerous studies showing the beneficial physiological effects of whey proteins and peptides, particularly in experiments with animals, we still have very limited knowledge about their effects in the human body. There is much to be assessed regarding the real mechanisms of action of these proteins and peptides and of the quantities that must be ingested to produce their beneficial effects [3]. Protein overload associated with the use of such supplements has been associated with physiological repercussions [4]. However, there is no consensus about the effects on renal morphology and function. Thus, the objective of the present study was to evaluate changes in glomerular filtration, renal tubular function, and histopathological alterations caused by the use of whey protein detary supplement on the kidneys of Wistar rats.

\section{Materials and Methods}

The study was conducted in the Facid DeVry Laboratory of Physiology after approval was granted by the ethics committee on the use of animals CEUA/FACID (protocol number 056/14) according to the ethical principles laid down by Law Arouca (No. 11.794/08). The entire experiment adhered to the ethical principles for animal experimentation recommended by the Brazilian College of Animal Experimentation (COBEA).

\section{Study type}

This was an experimental, longitudinal, interventionist, case-control study with a quantitative approach.

\section{Place of study}

The study was conducted at the Physiology Laboratory of the Facid DeVry Faculty, Teresina, Piauí State and North-eastern Brazil. 


\section{Studied population and experimental procedures}

Twelve adult Wistar male rats (Rattus norvegicus) weighing approximately $256.17 \mathrm{~g} \pm 21.94$ were kept at the Bioterium of the Physiology Laboratory, Faculdade Integral Diferencial, in plastic cages in an environment with controlled temperature, humidity, light, and noise with a 12-hour light-dark cycle. The animals were provided Purina balanced feed and water ad libitum.

The rats were randomly distributed into Group I (control; $n=6$ ), maintained with feed and filtered water ad libitum for 14 days; and Group II (intervention; $n=6$ ), given feed and filtered water ad libitum as well as daily supplementation 6 days a week of whey protein food supplement diluted in filtered water $(1 \mathrm{~g} / \mathrm{kg}$ body weight administered by gavage) for 14 days.

The food supplement was acquired from a commercial source and was composed of isolated whey protein, concentrated whey protein, whey peptides, cocoa, salt, natural and artificial flavoring, soy lecithin stabilizer, and the artificial sweeteners sucralose and acesulfame potassium.

The animals were kept in metabolic cages for 24 hours before the start of supplementation and after the administration of the last dose of food supplement for urine collection and the later physical and chemical assessment of abnormal elements and urinary sediment with the objective of evaluating glomerular and renal function using Bioeasy test strips. After the urine collection, the animals were anesthetized with ketamine chloride $100 \mathrm{mg} / \mathrm{kg}$ (Cristália) xylazine chloridrate $20 \mathrm{mg} / \mathrm{kg}$ (Anasedan) intraperitoneally. Once under anesthesia, the animals were subjected to a median thoracolaparotomy and 5-8 $\mathrm{mL}$ of blood was collected via puncture of the inferior vena cava. The blood was placed in glass tubes and centrifuged for 15 minutes at $2000 \mathrm{rpm}$ to obtain serum. Serum samples were stored in glass vials with stoppers in a freezer for the biochemical determination of urea, creatinine, sodium, potassium, and chloride levels to evaluate glomerular and tubular kidney function. Urea and creatinine were determined, respectively, by the kinetic-enzymatic and kineticcalorimetric method. Plasma sodium, potassium, and chloride levels were determined using the ion-selective electrode method.

After blood collection, the animals were euthanized in accordance with the appropriate ethical principles through sectioning of the diaphragm, which caused a pneumothorax and hypoxia-induced death. Subsequently, a bilateral nephrectomy was performed and the organs were fixed in $10 \%$ formalin, processed histologically to obtain 5 $\mu \mathrm{m}$ transversal slices, stained with hematoxylin and eosin, and evaluated under a Nikon light microscope.

The photomicrographs of histological sections of the kidneys were analyzed. The kidney sections were considered normal if they met the following criteria: well preserved with intact renal corpuscles and proximal and distal convoluted renal tubules; and no histological changes visible in the glomeruli consisting of capillaries, podocytes, or endothelial or mesangial cells. In the medullary region, the loop of Henle next to the capillaries and collector tubules, these with welldelimited cytoplasm and spherical nucleus, were considered normal. Other items confirmed, including intact Bowman capsule, presence of cubic or polyhedral cells, eosinophilic cytoplasm, and rounded nuclei.

\section{Statistical analysis}

Continuous random variables were submitted to D'Agostino and Pearson's normality test to assess the distribution of the data, followed by Student's $t$ test to assess differences in the means. The correlations of data of discrete random variables between classes were analyzed by the chi-square test. All tests were performed with the statistical program SPSS 19.0, with $95 \%$ confidence interval and significance set at values of $\mathrm{P}<0.05$.

\section{Results and Discussion}

All 12 animals (Wistar rats) were observed for 14 days. The results expressed in Table 1 show the values of body mass and serum biochemical analysis of the animals. The mean weight of the animals in Group I (control) was $274.5 \pm 22.12 \mathrm{~g}$ (range, 240-300 g). The average weight of the animals in Group II (intervention) was $256.17 \pm 21.94 \mathrm{~g}$ (range, 250-300 g). A statistically significant reduction in urea levels was observed $(41.77 \%$ [4.62] versus $31.83 \%$ [5.42]) $(\mathrm{P}=0.0093)$ between Groups I and II, respectively. There was an elevation, albeit statistically non-significant, of serum creatinine levels of Group II compared to Group I $(\mathrm{P}=0.2563)$. The renal tubular function of the animals in this study was evaluated through the assessment of serum and urinary sodium, potassium, and chloride. As shown in Table 1, there were no statistically significant changes in the levels of these electrolytes between Groups I and II $(\mathrm{P}=0.1392, \quad \mathrm{P}=0.1372$ and $\mathrm{P}=0.096$, respectively).

\begin{tabular}{|c|c|c|c|c|c|}
\hline \multirow[t]{2}{*}{ Variable } & \multicolumn{2}{|l|}{ Control } & \multicolumn{2}{|c|}{ Intervention } & \multirow{3}{*}{$\begin{array}{l}\mathbf{P} \\
0.1801\end{array}$} \\
\hline & M & SD & $\mathbf{M}$ & SD & \\
\hline Body mass index (g) & 256.17 & 21.94 & 274.50 & 22.12 & \\
\hline Urea (mg/dL) & 41.17 & 4.62 & 31.83 & 5.42 & $0.0093^{* *}$ \\
\hline Creatinine (mg/dL) & 0.50 & 0.07 & 0.56 & 0.10 & 0.2563 \\
\hline Sodium (mmol/L) & 138.92 & 1.10 & 137.70 & 1.50 & 0.1392 \\
\hline Potassium (mmol/L) & 5.12 & 0.32 & 6.75 & 2.45 & 0.1372 \\
\hline Chloride (mmol/L) & 169.18 & 29.52 & 146.18 & 9.59 & 0.0996 \\
\hline
\end{tabular}

Table 1: Body mass and plasma biochemical analysis of 12 wistar rats after whey protein dietary supplement use. 
The dietary intake of protein can modulate renal function, but there is no consensus as to its role in the pathogenesis of renal disease. Central to this controversy is the concern that the routine consumption of dietary protein above recommended levels promotes chronic renal disease due to hyperfiltration by increased glomerular pressure in contrast to the fact that studies in healthy individuals do not support this idea and that hyperfiltration constitutes a physiological response, i.e., an adaptive normal mechanism [5].

In the present study, even after supplementation with high protein content in Group II, no increase of this analyte was seen in the sera of the experimental animals. The results of this study corroborate the study of Martin et al. who reported that the renal impact due to a highprotein diet for a short period of time is different from the impact caused by a chronic consumption of this type of diet; therefore, the supplementation period of 14 days was insufficient to cause a significant change in the protein metabolism and increased level of this metabolite [6]. The serum urea generally does not increase until more than $60 \%$ of nephrons do not function; therefore, this is a high specificity but low sensitivity marker [7].

The study evaluating the role of protein intake in glomerular filtration performed by Bosch et al. led to the introduction of the renal functional reserve concept, which consists of the difference in glomerular filtration rate (GFR) that occurs between the basal state and after feeding [8]. According to these authors, creatinine is increasingly excreted not only due to higher tubular secretion after protein intake, thus leading to an increase of the GFR, but also due to the ingestion of creatinine that accompanies protein intake [8].

Healthy vegetarians are known to have a statistically reduced baseline GFR but a maintained ability to increase the GFR after a protein-rich diet unlike patients with a reduced number of nephrons whose renal functional reserve can be decreased or absent [9]. Another mechanism suggested to increase the GFR was the reduced sensitivity of glomerulotubular balance. This hypothesis is based on the fact that there is an increase in sodium reabsorption in the proximal tubule after the ingestion of a high-protein diet. The increase in sodium reabsorption in the proximal portion of the nephron would entail less sodium load in the macula densa; thus, an increase in the glomerular filtration per nephron could occur [10].

Although the effect of hyperfiltration on the renal function of individuals with renal disease and pre-existing risk factors is well documented, the application of these findings to healthy people with normal renal function is not appropriate. To date, no clinical or experimental study has correlated protein-induced renal hypertrophy or hyperfiltration with the initiation of renal disease in healthy individuals. A 10-year prospective cohort study of middle-aged women found no correlation between high-protein diets and an increased risk of renal function decline [11].

The renal tubular function of the animals in this study was evaluated through the assessment of urinary sodium, potassium, and chloride through the analysis. As shown in Table 1, no statistically significant alterations in the levels of these electrolytes were observed between Groups I and II.

After conducting a study in animals of various species with application of a protein-rich diet and aiming to evaluate renal excretory function induced by such dietary changes, the results of Singer's study, unlike those of the present study, concluded that the animals generally responded to an increased intake of protein with a change in renal excretory function to increase the elimination of the major nitrogenous end products of protein metabolism. The components of this response include a redistribution of regional perfusion with an increase in renal blood flow (RBF), increased GFR and ammonia clearance, increased tubular renal clearance of urea, changes in protein transport, and renal hypertrophy. The catabolism of amino acids with the production of ammonia seems to be a necessary prerequisite for this excretory response to occur because ammonia is a regulatory molecule and an important communication signal between the catabolism of amino acids following an increase in protein intake and the sequence of events that lead to changes in excretory function [12].

Other studies, in agreement with the results of this study, showed that protein-rich diets do not or only slightly change the serum levels of electrolytes but without clinical manifestations [13].

The physical analysis of the animals' urine revealed an increase in density after the intervention; however, the difference was not statistically significant (Table 2). The assessment of urinary density is a very useful test for the evaluation of dilution and renal concentration capacity. Loss of renal concentration capacity is usually the first sign of tubular renal disease. The urine-specific gravity varies with body hydration, fluid intake, and serum osmolarity. In agreement with the results of this study, the presence of proteinuria and marked glycosuria, urinary density can be increased, leading to the interpretation that the renal tubules have a greater capacity for urine concentration in the presence of those molecules [14].

\begin{tabular}{|c|c|c|c|c|c|c|}
\hline \multirow[t]{2}{*}{ Variable } & & \multicolumn{2}{|l|}{ Control } & \multicolumn{2}{|l|}{ Intervention } & \multirow[t]{3}{*}{$x^{2}$} \\
\hline & & $\mathrm{n}$ & $\%$ & $\mathrm{n}$ & $\%$ & \\
\hline \multicolumn{2}{|c|}{ Color } & & & & & \\
\hline \multirow[t]{3}{*}{ Before ${ }^{*}$} & & & & & & \\
\hline & Amber & 6 & $100 \%$ & 6 & $100 \%$ & - \\
\hline & Other Color & 0 & $0 \%$ & 0 & $0 \%$ & \\
\hline \multicolumn{7}{|l|}{ After $^{* *}$} \\
\hline & Amber & 6 & $100 \%$ & 6 & $100 \%$ & \multirow[t]{2}{*}{ 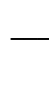 } \\
\hline & Other Color & 0 & $0 \%$ & 0 & $0 \%$ & \\
\hline
\end{tabular}


Citation: Silva AAA, Rodrigues AG, da Silva AA, Silva CAA (2016) Functional and Morphostructural Evaluation of the Kidneys of Wistar Rats after the Use of a Protein-Based Food Supplement. J Nephrol Ther 6: 270. doi:10.4172/2161-0959.1000270

Page 4 of 8

\begin{tabular}{|c|c|c|c|c|c|c|}
\hline \multicolumn{7}{|c|}{ Appearance } \\
\hline \multicolumn{7}{|l|}{ Before $^{*}$} \\
\hline & Cloudy & & $100 \%$ & 6 & $100 \%$ & \multirow[t]{2}{*}{ - } \\
\hline & Other & & $0 \%$ & 0 & $0 \%$ & \\
\hline \multicolumn{7}{|l|}{ After } \\
\hline & Cloudy & & $100 \%$ & 6 & $100 \%$ & \multirow{2}{*}{ - } \\
\hline & Other & & $0 \%$ & 0 & $0 \%$ & \\
\hline \multicolumn{7}{|c|}{ Density } \\
\hline \multirow[t]{5}{*}{ Before $^{*}$} & & & & & & 0.1577 \\
\hline & 1000 & 3 & $50 \%$ & 2 & $33 \%$ & \\
\hline & 1010 & 1 & $17 \%$ & 1 & $17 \%$ & \\
\hline & 1015 & 0 & $0 \%$ & 3 & $50 \%$ & \\
\hline & 1020 & 2 & $33 \%$ & 0 & $0 \%$ & \\
\hline \multirow[t]{4}{*}{ After } & & & & & & 0.4645 \\
\hline & 1020 & 3 & $25 \%$ & 2 & $17 \%$ & \\
\hline & 1025 & 2 & $17 \%$ & 1 & $8 \%$ & \\
\hline & 1030 & 1 & $8 \%$ & 3 & $25 \%$ & \\
\hline $\begin{array}{l}\text { M: mean; SD: standa } \\
\text { "Before supplementa } \\
\text { Values expressed as }\end{array}$ & $\begin{array}{l}\text { zalues de } \\
\text { lementat }\end{array}$ & ing $t$ & test with a & int & & \\
\hline
\end{tabular}

Table 2: Physical analysis of the urine of 12 wistar rats before and after whey protein dietary supplement use.

The chemical analysis of the animals' urine showed a significant difference in qualitative proteinuria after intervention between groups (Table 3). Increase in protein excretion has diagnostic or prognostic value in the initial detection and confirmation of renal disease, while the quantification of proteinuria can have considerable significance in the evaluation of therapeutic efficacy and disease progression [15].

\begin{tabular}{|c|c|c|c|c|c|c|}
\hline \multirow[t]{2}{*}{ Variables } & & \multicolumn{2}{|c|}{ Control } & \multicolumn{2}{|c|}{ Intervention } & \multirow[t]{2}{*}{$x^{2}$} \\
\hline & & 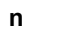 & $\%$ & $n$ & $\%$ & \\
\hline \multicolumn{7}{|c|}{ Reaction } \\
\hline \multirow[t]{2}{*}{ Before $^{*}$} & Acid & 0 & $0 \%$ & 0 & $0 \%$ & \multirow[t]{2}{*}{-} \\
\hline & Alkaline & 6 & $100 \%$ & 6 & $100 \%$ & \\
\hline \multirow[t]{2}{*}{ After $^{* *}$} & Acid & 0 & $0 \%$ & 0 & $0 \%$ & \multirow[t]{2}{*}{ - } \\
\hline & Alkaline & 6 & $100 \%$ & 6 & $100 \%$ & \\
\hline \multicolumn{7}{|c|}{ Protein } \\
\hline Before $^{*}$ & + & 4 & $67 \%$ & 1 & $17 \%$ & \multirow[t]{4}{*}{$0.0465^{*}$} \\
\hline & ++ & 0 & $0 \%$ & 4 & $67 \%$ & \\
\hline & +++ & 0 & $0 \%$ & 0 & $0 \%$ & \\
\hline & ++++ & 0 & $0 \%$ & 0 & $0 \%$ & \\
\hline
\end{tabular}


Citation: Silva AAA, Rodrigues AG, da Silva AA, Silva CAA (2016) Functional and Morphostructural Evaluation of the Kidneys of Wistar Rats after the Use of a Protein-Based Food Supplement. J Nephrol Ther 6: 270. doi:10.4172/2161-0959.1000270

Page 5 of 8

\begin{tabular}{|c|c|c|c|c|c|c|}
\hline & Absent & 2 & $33 \%$ & 1 & $17 \%$ & \\
\hline \multirow[t]{5}{*}{ After ${ }^{* *}$} & + & 3 & $50 \%$ & 0 & $0 \%$ & \multirow[t]{5}{*}{$0.0404^{*}$} \\
\hline & ++ & 1 & $17 \%$ & 1 & $17 \%$ & \\
\hline & +++ & 0 & $0 \%$ & 4 & $67 \%$ & \\
\hline & ++++ & 0 & $0 \%$ & 1 & $17 \%$ & \\
\hline & Absent & 2 & $33 \%$ & 0 & $0 \%$ & \\
\hline \multicolumn{7}{|c|}{ Hemoglobin } \\
\hline \multirow[t]{2}{*}{ Before $^{*}$} & Present & 0 & $0 \%$ & 0 & $0 \%$ & \multirow{4}{*}{-} \\
\hline & Absent & 6 & $100 \%$ & 6 & $100 \%$ & \\
\hline \multirow[t]{2}{*}{ After $^{* *}$} & Present & 0 & $0 \%$ & 0 & $0 \%$ & \\
\hline & Absent & 6 & $100 \%$ & 6 & $100 \%$ & \\
\hline \multicolumn{7}{|l|}{ Glucose } \\
\hline \multirow[t]{2}{*}{ Before* $^{*}$} & Present & 0 & $0 \%$ & 0 & $0 \%$ & \multirow[t]{4}{*}{-} \\
\hline & Absent & 6 & $100 \%$ & 6 & $100 \%$ & \\
\hline \multirow[t]{2}{*}{ After ${ }^{* *}$} & Present & 0 & $0 \%$ & 0 & $0 \%$ & \\
\hline & Absent & 6 & $100 \%$ & 6 & $100 \%$ & \\
\hline \multicolumn{7}{|c|}{ Ketone bodies } \\
\hline \multirow[t]{2}{*}{ Before $^{*}$} & Present & 0 & $0 \%$ & 0 & $0 \%$ & \multirow[t]{2}{*}{-} \\
\hline & Absent & 6 & $100 \%$ & 6 & $100 \%$ & \\
\hline \multirow[t]{2}{*}{ After } & Present & 0 & $100 \%$ & 1 & $17 \%$ & \multirow[t]{2}{*}{0.2962} \\
\hline & Absent & 6 & $100 \%$ & 5 & $83 \%$ & \\
\hline \multicolumn{6}{|l|}{ Bilirubin } & \multirow{5}{*}{-} \\
\hline Before* $^{*}$ & Present & 0 & $0 \%$ & 0 & $0 \%$ & \\
\hline & Absent & 6 & $100 \%$ & 6 & $100 \%$ & \\
\hline \multirow[t]{2}{*}{ After ${ }^{* *}$} & Present & 0 & $0 \%$ & 0 & $0 \%$ & \\
\hline & Absent & 6 & $100 \%$ & 6 & $100 \%$ & \\
\hline \multicolumn{7}{|c|}{ Urobilinogen } \\
\hline \multirow[t]{2}{*}{ Before* $^{*}$} & Present & 0 & $0 \%$ & 0 & $0 \%$ & \multirow[t]{4}{*}{-} \\
\hline & Absent & 6 & $100 \%$ & 6 & $100 \%$ & \\
\hline \multirow[t]{2}{*}{ After ${ }^{\star *}$} & Present & 0 & $0 \%$ & 0 & $0 \%$ & \\
\hline & Absent & 6 & $100 \%$ & 6 & $100 \%$ & \\
\hline $\begin{array}{l}\text { M: mean; SD: standa } \\
\text { "Before supplementa } \\
\text { Values expressed as }\end{array}$ & $\begin{array}{l}\text { values det } \\
\text { lementatic }\end{array}$ & us & are test $\mathrm{v}$ & lenc & & \\
\hline
\end{tabular}

Table 3: Chemical urinalysis of 12 wistar rats before and after whey protein dietary supplement use.

Epidemiological data regarding the changes in urinary excretion of proteins due to high-protein diets are not consensual. A study conducted by Hoogeveen et al. showed that the risk of microalbuminuria increases progressively with the increase of protein intake [16], while Wrone et al. stated that protein intake is a risk factor for microalbuminuria only in individuals with diabetes and 
Citation: Silva AAA, Rodrigues AG, da Silva AA, Silva CAA (2016) Functional and Morphostructural Evaluation of the Kidneys of Wistar Rats after the Use of a Protein-Based Food Supplement. J Nephrol Ther 6: 270. doi:10.4172/2161-0959.1000270

Page 6 of 8

hypertension [17]. Metcalf et al. found no correlation between albuminuria and protein intake [18].

In the present study, an increase in ketone bodies was observed in the urine of the animals of the intervention group. Protein intake above the physiological need leads to the increase in the catabolic pathways of amino acids, increasing the production of by-products such as urea, adenosine triphosphate (ATP), carbon dioxide, glucose, acetyl coenzyme A, and ketone bodies. Some of these by-products can have adverse effects in the body [19].
Data relating to urinary sediment (Table 4) showed that most of the animals of Group II presented with granular and waxy casts after the intervention. Granular and waxy casts represent successive stages in the degeneration of the cellular casts as they pass through the nephrons. Besides representing cellular remnants, the granules present in these casts can also represent aggregates of plasmatic proteins, i.e., granular casts can appear in any pathology that accompanies proteinuria [20].

\begin{tabular}{|c|c|c|c|c|c|c|}
\hline \multirow[t]{2}{*}{ Variables } & & \multicolumn{2}{|c|}{ Control } & \multicolumn{2}{|c|}{ Intervention } & \multirow[t]{2}{*}{$x^{2}$} \\
\hline & & N & $\%$ & $n$ & $\%$ & \\
\hline \multicolumn{7}{|l|}{ Nitrite } \\
\hline \multirow[t]{2}{*}{ Before $^{*}$} & Present & 0 & $0 \%$ & 0 & $0 \%$ & - \\
\hline & Absent & 6 & $100 \%$ & 6 & $100 \%$ & \\
\hline \multirow[t]{2}{*}{ After* } & Present & 0 & $0 \%$ & 0 & $0 \%$ & \\
\hline & Absent & 6 & $100 \%$ & 6 & $100 \%$ & - \\
\hline \multicolumn{7}{|c|}{ Epithelial cells } \\
\hline \multirow[t]{2}{*}{ Before $^{*}$} & Present & 5 & $83 \%$ & 5 & $83 \%$ & \\
\hline & Absent & 1 & $17 \%$ & 1 & $17 \%$ & 1 \\
\hline \multirow[t]{2}{*}{ After ${ }^{* *}$} & Present & 4 & $67 \%$ & 3 & $50 \%$ & \\
\hline & Absent & 2 & $33 \%$ & 3 & $50 \%$ & 0.5581 \\
\hline \multicolumn{7}{|l|}{ Crystals } \\
\hline \multirow[t]{5}{*}{ Before $^{*}$} & $\begin{array}{ll}\text { Few } & \text { triple } \\
\text { phosphate } & \end{array}$ & 0 & $0 \%$ & 5 & $83 \%$ & \\
\hline & $\begin{array}{l}\text { Several } \\
\text { phosphate }\end{array}$ & 0 & $0 \%$ & 0 & $0 \%$ & \\
\hline & $\begin{array}{l}\text { Few calcium } \\
\text { oxalate }\end{array}$ & 5 & $83 \%$ & 0 & $0 \%$ & \\
\hline & $\begin{array}{l}\text { Several calcium } \\
\text { oxalate }\end{array}$ & 0 & $0 \%$ & 0 & $0 \%$ & \\
\hline & Absent & 1 & $17 \%$ & 1 & $17 \%$ & $0.0067^{*}$ \\
\hline \multirow[t]{5}{*}{ After* } & $\begin{array}{l}\text { Few } \\
\text { phosphate }\end{array}$ & 4 & $67 \%$ & 1 & $17 \%$ & \\
\hline & $\begin{array}{l}\text { Several } \\
\text { phosphate }\end{array}$ & 1 & $17 \%$ & 3 & $50 \%$ & 0.2087 \\
\hline & $\begin{array}{l}\text { Few calcium } \\
\text { oxalate }\end{array}$ & 0 & $0 \%$ & 0 & $0 \%$ & \\
\hline & $\begin{array}{l}\text { Several calcium } \\
\text { oxalate }\end{array}$ & 0 & $0 \%$ & 0 & $0 \%$ & - \\
\hline & Absent & 1 & $17 \%$ & 2 & $33 \%$ & - \\
\hline \multicolumn{7}{|l|}{ Casts } \\
\hline \multirow[t]{2}{*}{ Before $^{*}$} & Waxy & 3 & $50 \%$ & 2 & $33 \%$ & 0.5581 \\
\hline & Absent & 3 & $50 \%$ & 4 & $67 \%$ & \\
\hline
\end{tabular}


Citation: Silva AAA, Rodrigues AG, da Silva AA, Silva CAA (2016) Functional and Morphostructural Evaluation of the Kidneys of Wistar Rats after the Use of a Protein-Based Food Supplement. J Nephrol Ther 6: 270. doi:10.4172/2161-0959.1000270

Page 7 of 8

\begin{tabular}{|l|l|l|l|l|l|l|}
\hline After* $^{* *}$ & Waxy & 1 & $17 \%$ & 4 & $67 \%$ & 0.0789 \\
\cline { 2 - 7 } & Absent & 5 & $83 \%$ & 2 & $33 \%$ & \\
\hline $\begin{array}{l}\text { M: mean; SD: standard deviation; } X^{2} \text { values determined using the Chi-square test with a 95\% confidence interval *Before supplementation; **After supplementation } \\
\text { Values expressed as n (\%) }\end{array}$
\end{tabular}

Table 4: Urinary sediment analysis of 12 wistar rats before and after whey protein dietary supplement use.

In the present study, no histological alterations were observed in the kidneys of Group I animals (Figure 1). In Group II, however, in the majority of the kidneys (62\%), areas with peritubular blood vessel dilation and some congested glomeruli were observed (Figure 2). Studies in humans and animals have shown that protein intake influences intrarenal hemodynamic, which acutely increases the GFR and RBF by up to $100 \%$ of that of the basal level, Brenner et al. postulated that protein intake determined a glomerular vasodilation with a resulting increase in the capillary hydrostatic pressure and GFR. These hemodynamic renal changes would occur after each proteincontaining meal and retain a state of chronic renal vasodilation that would encourage the development of glomerulopathy in patients who already had some degree of renal lesion. According to these authors, renal hemodynamic changes would be important for the initiation and progression of glomerulosclerosis. The increase in the intracapillary hydrostatic pressure and increased GFR would alter the selectivity of the glomerular membrane, favouring a greater flow of plasma proteins that would accumulate in the mesangium, act as a stimulus for the production of the mesangial matrix, and contribute to the process of glomerulosclerosis [21].

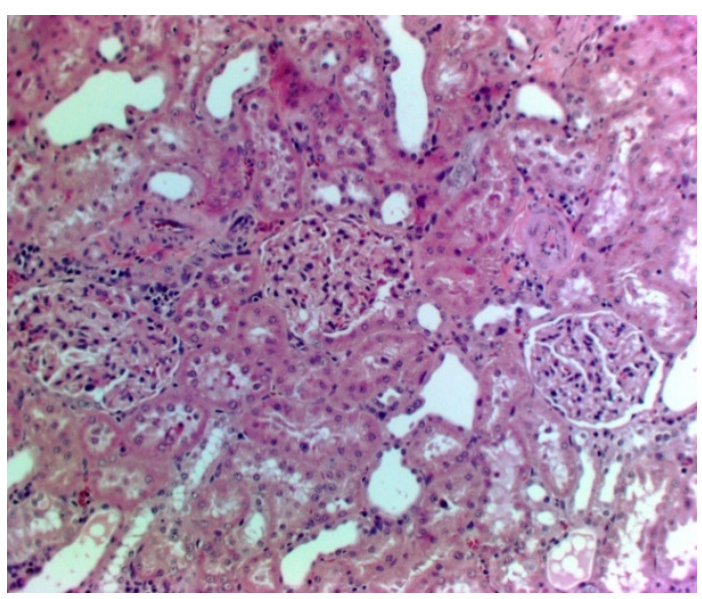

Figure 1: Photomicrograph of a kidney of a group I animal (control) showing normal glomeruli, tubules, and interstitium.

The long-term hemodynamic effect of a high protein diet on the healthy kidney is not well understood. Rats fed a diet rich in lacto proteins for 6 months did not show any manifestation of renal disease upon histological examination despite evidence of dramatic changes in the body composition compared to that of the control group [22].

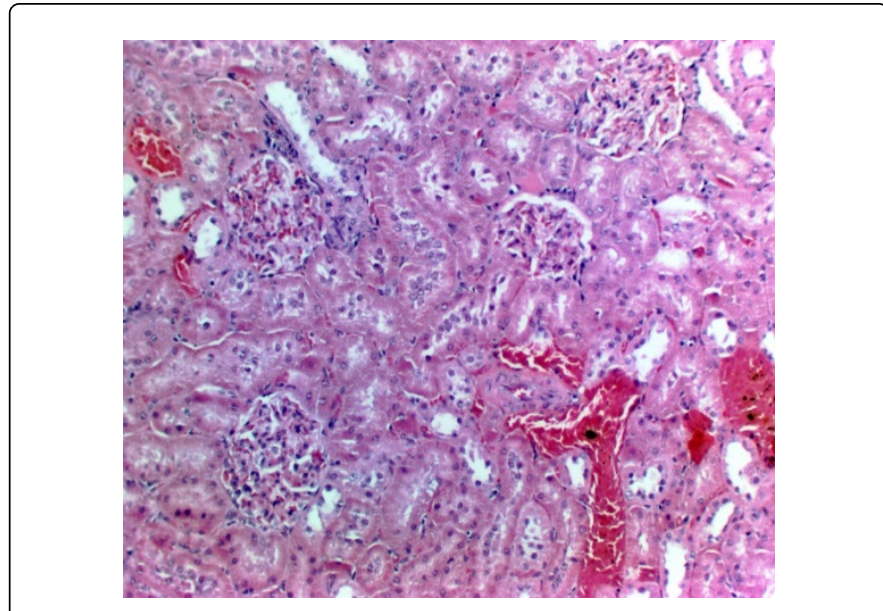

Figure 2: Photomicrograph of a kidney of an animal of group II (intervention) showing peritubular vascular congestion and mild glomerular congestion.

Experimental conditions point to the fact that high-protein diets induce significant increases in GFR and RBF that have deleterious effects on renal function. However, the impact of a high-protein diet on the kidney of a healthy individual who adopts this type of diet for relatively short periods is not well established [23].

In disagreement with, here we found no changes in glomerular and tubular cellularity or in nephron hypertrophy of the animals after protein supplementation. According to the aforementioned authors, a high protein intake increases the proximal reabsorption of sodium evidenced by increased activity of the $\mathrm{Na}+\mathrm{H}+$ exchanger in the proximal tubule. The increased protein load in the diet causes hypertrophy of the entire nephron but particularly in the thick limb of the loop of Henle, with an increase in Na-K-ATPase pump activity in the basolateral membrane of this segment [24].

\section{Conclusions}

The present study demonstrated that the use of the whey protein food supplement on the kidneys of Wistar rats during a short period caused a change in glomerular and tubular filtration as evidenced by the significant increase in proteinuria. Histopathological evaluation revealed that the high-protein diet caused peritubular glomerular and vascular congestion.

\section{References}

1. Araújo AC, Soares YN (1999) Pattern of utilization of protein supplements in academies in Belém, Pará. Rev Nutr 12: 81-89. 
Citation: Silva AAA, Rodrigues AG, da Silva AA, Silva CAA (2016) Functional and Morphostructural Evaluation of the Kidneys of Wistar Rats after the Use of a Protein-Based Food Supplement. J Nephrol Ther 6: 270. doi:10.4172/2161-0959.1000270

Page 8 of 8

2. Kreider RB, Miriel V, Bertun E (1993) Amino acid supplementation and exercise performance. Analysis of the proposed ergogenic value. Sports Med 16: 190-209.

3. Sgarbieri VC (2004) Propriedades fisiológicas-funcionais das proteínas do soro de leite. Rev Nutr 17: 397-409.

4. Paiva AC, Alfenas RCG, Bressan J (2007) Efeitos da alta ingestão diária de proteínas no metabolismo. Rev Bras Nutr Clin 22: 83-88.

5. Wada T, Nakao T, Matsumoto H (2015) Relationship between dietary protein and the changes in creatinine clearance an glomerular crosssectional area in patients with IgA nephropathy. Clin Exp Nephol 19: 661-668.

6. Martin WF, Armstrong LE, Rodriguez NR (2005) Dietary protein intake and renal function. Nutr Metab (Lond) 2: 25.

7. Menezes LB, Fioravanti MC, Silva MSB (2010) Avaliação do efeito da clorpromazina sobre a função renal de cães submetidos à isquemia e reperfusão. Pesq Vet Bras. Rio de Janeiro 30: 108-114.

8. Bosch JP, Saccaggi A, Lauer A, Ronco C, Belledonne M, et al. (1983) Renal functional reserve in humans. Effect of protein intake on glomerular filtration rate. Am J Med 75: 943-950.

9. Lohsiriwat S (2013) Protein diet and estimated glomerular filtration rate. Open J Nephrol 3: 97-100.

10. Harris RC, Seifter JL, Brenner BM (1984) Adaptation of Na+-H+ exchange in renal microvillus membrane vesicles. Role of dietary protein and uninephrectomy. J Clin Invest 74: 1979-1987.

11. Knight EL, Stampfer MJ, Hankinson SE, Spiegelman D, Curhan GC (2003) The impact of protein intake on renal function decline in women with normal renal function or mild renal insufficiency. Ann Intern Med 138: 460-467.

12. Singer MA (2003) Dietary protein-induced changes in excretory function: a general animal design feature. Comp Biochem Physiol B Biochem Mol Biol 136: 785-801.

13. Nankivell BJ, Tay YC, Boadle RA, Herris DC (1994) Dietary protein alters tubular irion accumulation after partial nephrectomy. Kidney Int 45: 1006-1013.

14. Reine NJ, Langston CE (2005) Urinalysis interpretation: how to squeeze out the maximum information from a small sample. Clin Tech Small Anim Pract 20: 2-10.
15. Forterre S, Raila J, Schweigert FJ (2004) Protein profiling of urine from dogs with renal disease using ProteinChip analysis. J Vet Diagn Invest 16: 271-277.

16. Hoogeveen EK, Kostense PJ, Jager A, Heine RJ, Jakobs C, et al. (1998) Serum homocysteine level and protein intake are related to risk of microalbuminuria: The Hoorn Study. Kidney Int 54: 203-209.

17. Wrone EM, Carnethon MR, Palaniappan L, Fortmann SP, Third National Health et al. (2003) Association of dietary protein intake and microalbuminuria in healthy adults: Third National Health and Nutrition Examination Survey. Am J Kidney Dis 41: 580-587.

18. Metcalf PA, Baker JR, Scragg RK, Dryson E, Scott AJ, et al. (1993) Dietary nutrient intakes and slight albuminuria in people at least 40 years old. Clin Chem 39: 2191-2198.

19. Fanti P, Giustarini D, Rossi R, Cunningham SE, Folli F, et al. (2015) Dietary intake of protein an calories in inversely associated with the oxidation state of plasma thiols in end-stage renal disease patients. J Ren Nutr 25: 494-503.

20. Remer T, Esche J, Krupp D (2016) Increased protein intake and corresponding renal acid load under a concurrent alkalizing diet regime. Physiol Rep 4: ${ }^{\text {el2851. }}$.

21. Brenner BM, Meyer TW, HostetteR TH (1982) Dietary protein intake and the progressive nature of kidney disease: the role of hemodynamically mediated glomerular injury in the pathogenesis of progressive glomerular sclerosis in aging, renal ablation, and intrinsic renal disease. $\mathrm{N}$ Engl J Med 307: 652-659.

22. Lacroix M, Gaudichon C, Martin A, Morens C, Mathé V, et al. (2004) A long-term high-protein diet markedly reduces adipose tissue without major side effects in Wistar male rats. Am J Physiol Regul Integr Comp Physiol 287: R934-942.

23. Shah BV, Patel ZM (2016) Role of low protein diet in management of different stages of chronic kidney disease - practical aspects. BMC Nephrol 17: 156.

24. Rodriguez-iturbe B, Herrera J, Garcia R (1988) Relationship between glomerular filtration rate and renal blood flow at different levels of protein induced hyperfiltration in man. Clin Sci (Colch) 74: 11-15. 